International Journal of Agriculture, Environment and Bioresearch

Vol. 06, No. 01; 2021

ISSN: $2456-8643$

\title{
NON-GENETIC FACTORS AFFECTING GROWTH PERFORMANCE OF MARADI GOAT AND ESTIMATION OF HERITABILITY
}

\author{
Karimou Harouna Boureima \\ Tel.: (+227) 73.54.54 Or (+227) 96 49.40.21 \\ https://doi.org/10.35410/IJAEB.2021.5600
}

\begin{abstract}
The study of the non-genetic factors (season of birth, year of birth, sexes, type of birth) influencing weight gain from birth to three months ( weaning), from three to nine months (after weaning), from birth to nine months (from birth to adulthood) and the corresponding average daily gain of Maradi goat was carried out. Data concerned 324 animals from the Caprine Center of Maradi, born from 1996 to 2000. The season of birth had a highly significant effect on the weight at birth $(\mathrm{P}<0.0001)$, on the average daily weight gain from birth to three months $(\mathrm{P}<$ $0.0001)$, and from birth to nine months $(\mathrm{P}<0.001)$. The best growth performances were observed in animals born during the rainy season (S3) than in other seasons (BW (S3) $=2.28 \mathrm{~kg}, \mathrm{BW}(\mathrm{S} 2)$ $=1.97 \mathrm{~kg} \mathrm{BW}(\mathrm{S} 3)=2.1 \mathrm{~kg})$. The year of birth influenced significantly one month weight and the average daily gain from birth to nine months $(\mathrm{P}<0.005)$. The effect of the sexes was significant on the birth weight $(\mathrm{P}<0.001)$ and the average daily gain from birth to nine months $(\mathrm{P}<0.01)$. Heritability estimates varied from 0.15 to 0.8 (from birth to nine month). This study show the importance of non genetic and gentics factors and could be taken into account in further genetic improve of Maradi goat.
\end{abstract}

Keywords: Maradi goat; non-genetic Factors; Average daily gain; Weight; Growth rate; Heritability; Niger.

\section{INTRODUCTION}

The caprine sector of Niger presents two races: (1) the West African long legged goat adapted to the long courses (in the north), with black, white and red spots on the coal; (2) the Maradi goat adapted to sedentary breeding areas, Doutressoule (1947). A marked dryness remains fatal for Niger breeding sector, in particular that of years 1973 and 1980. According to Gani (2000) the number of the bovines fell of 50\% in 30 years for the benefit of the small ruminants and the dromedaries. Only the caprine that are well adapted to the difficult conditions of the climate manage their selves to survive with good performances. The contribution on the nutritive level of the caprine breeding is not to neglect (737129 carcass of goat and $104.808 .003 \mathrm{~kg}$ of milk produce in 2003, knowing that Niger milk production is estimated for all the animals at $303.632 .498 \mathrm{~kg}$ at the same time) 
In Niger, the caprine occupied the first rank from 1965 to 2005 because of their excellent prolificacy and capacity of adaptation to sahel climatic rigours (9.635.900 for 2005). Goat breeding can be practised where that of the cow is practically impossible (Haenlein, 1978). The advantage of the caprine breeding lies in its precocity, its multiple ranges, its shorter interval between generations and its gestation period from 5 to 6 months authorizing three kids every two years (Devendra, 1980). The goat's milk contains more calcium and more phosphorus than of women (Jenness, 1980). So in the wandering areas of Niger, the orphan children are fed with the goat's milk until weaning. As regard to all that proceeds, it is an imperative for developing countries as Niger, for food self-sufficiency and the reduction of poverty (Faye 2001), to be directed towards the genetic improvement and the production of species with short cycles. The Maradi goat shows today a decreasing aptitudes (in Maradi caprine centre) point out by a decreasing prolificacy from 147\% (Haumesser, 1975) to $125.26 \%$ (Anonym 1999), a decreasing weights at birth from $2.05 \mathrm{~kg}$ (Haumesser, 1975) to $1.8 \mathrm{~kg}$ (Oumara, 1986), a lower fruitfulness from $123.2 \%$ in 1996, 107.36\% in 1997 to $83.62 \%$ in 1998 (Marichatou et al., 2002), and a drop of fertility from $87.07 \%$ in $1996,79.14 \%$ in 1997 to $65.02 \%$ in 1998 .

It is accepted that animal performances are determinate by the genotype expression in interaction with non-genetic factors, thus the present study was purposed to put forward the non-genetic factors influencing the growth rates of Maradi goat in order to select the well adapted subjects, with good performances, easily exploitable for long period with best results.

\section{MATERIALS AND METHODS}

\subsection{Study area and animal management}

The study was conducted at Maradi goat centre in middle of Niger, between $13^{\circ} 02$ Northern latitude and $6^{\circ}$ 15longitude East. The temperatures are very high (average: $32^{\circ} \mathrm{c}$ ), annual precipitations are variable and frequently insufficient (from north to south, annual precipitations average vary from $300 \mathrm{~mm}$ to $700 \mathrm{~mm}$ ).

Three seasons are observed during the year: (1) one dry and hot season $\left(32^{\circ} \mathrm{c}\right)$ from March to June; (2) one rainy season from July to October; (3) and the cold season $\left(22^{\circ} \mathrm{c}\right)$ from November to February.

A total of 324 kids were followed between 1996 and 2000. The animals were housed overnight without categorisation; identified using ear tag; and they are exit to pasture for $7 \mathrm{~h}$ per day ( $8 \mathrm{~h}$ to $12 \mathrm{~h}$ and $14 \mathrm{~h}$ to $17 \mathrm{~h})$.

The pasture was composed by graminaceous: Eragrotis tremula, Loudeta hordeiformis, Diheteropogon hagerupei, Andropogon gayanus, Ctenium elegans (their productivity is estimated at $2.200 \mathrm{~kg} \mathrm{MS} / \mathrm{ha} / \mathrm{year}$ ), and pasture coming from the ligneous family like: Guiera senegalensis, Prosopis africana, Cochlospermum planchoni, Combretum, Sclerocarya birrea, Acacia, (715kg MS/ha/year). Animals were supplemented only in dry season with cotton seeds, wheat bran, leaf of groundnut and bean, water is given ad libitum. Heath management consisted on systematic vaccination each year against goat plague and pasteurollose; treated tree times a 
year for endoparasites (at the beginning, in middle and at the end of the rainy season), but occasionally treated against ecto-parasites.

\subsection{Data collection}

Data were recorded on 324 kids born from 1996 to 2000. They were weighted using spring (carried $50 \mathrm{~kg}$ ) for monthly weight from birth to nine months age. Corresponding

average daily gains (ADG) from birth to 3 months $\left(\mathrm{ADG}_{03}\right)$, from 3 to 9 months $\left(\mathrm{ADG}_{39}\right)$ and from birth to 9 months $\left(\mathrm{ADG}_{09}\right)$ were calculated.

\subsection{Statistical Analysis}

Data were analysed using a general procedure (proc. GLM) of SAS (1989). The fixed model used was:

$\mathrm{Y}_{\mathrm{ijk} \mathrm{l}}=\mu+\mathrm{SN}_{\mathrm{i}}+\mathrm{AN}_{\mathrm{j}}+\mathrm{S}_{\mathrm{k}}+\mathrm{e}_{\mathrm{ijkl}}$

$\mathrm{Y}_{\mathrm{ijkl}}=$ weight daily gain of the first kid, born in season $\mathrm{i}$ of year $\mathrm{j}$ and with the sexe $\mathrm{k}$

$\mu=$ value of the general average.

$\mathrm{SNi}=$ fixed effects of birth season $\mathrm{i}(1=\mathrm{S} 1$ : from November to February (cold season), $2=\mathrm{S} 2$ : from March to June (hot season); 3= S3: from July to October (rainy season)).

$\mathrm{AN}_{\mathrm{j}}=$ fixed effects of birth year $\mathrm{j}$, five classes $(1=1996 ; 2=1997 ; 3=1998 ; 4=1999 ; 5=2000)$.

$S_{k}=$ fixed effect of sex $\mathrm{k}$ ( 2 classes: $1=$ Male and 2=Female).

$(\mathrm{SN}+\mathrm{AN}) \mathrm{ij}=$ interaction between year of birth and season of birth.

$\mathrm{E}_{\mathrm{ijk} \mathrm{l}}=$ residual effect random .

The interaction between year and season of birth was significant. variables were Overall growth performances, , average daily gain from birth to three months $\left(\mathrm{ADG}_{03}\right)$, from three to nine months $\left(\mathrm{ADG}_{39}\right)$ and from birth to nine months $\left(\mathrm{ADG}_{09}\right)$. GLM (General Linear Models Procedure of SAS (Statistical Analysis System, 1989) was used. The least squares means were considered and compared by Student $t$-test. The share of the variation $\mathrm{R}^{2}(\%)$ explained by the model and each non-genetic factor was calculated according to the methodology described by Searle (1971), by using the method of the reduction of the sum of the squares of the model $\left(R^{2}\right)$ (presence or absence of the factor)

The type of birth could not be taken into account in the linear model because of the absence of sufficient information, the analyses have been summers made via the procedure of statistica *, just to determinate growth curves. 
Heritability estimates was computed by the method of paternal half-sib analysis using VARCOMP procedures of SAS (1987).

\section{RESULTS AND DISCUSSION}

The results of variance analysis, least square means \pm standard error, for adjusted weights and average daily gain, the weight performance according to the season and the year of birth, the sexes are represented in table 1. Results of Maradi goat bodyweight according to the type of birth are in table 2.

The level of significance of fixed effect and $\mathrm{R}^{2}(\%)$ indicated by the model, and the variation of the fixed factors explained by the model are presented respectively in figure 1 and 2 . Comparison of growth performances are in table 3; and_Results and discussion for heritability are presented in table 4 .

\section{Season of birth}

The effect of birth season was very significant $(\mathrm{P}<0.001)$ on the weigh performances and the average daily gains. The animals born during the rainy season $\left(\mathrm{S}_{3}\right)$ were heavier $(\mathrm{BW}=2.28 \mathrm{~kg})$ than those of the other seasons $\left(\mathrm{S}_{2}, \mathrm{BW}=2.14 \mathrm{~kg}\right.$ and $\left.\mathrm{S}_{1}, \mathrm{BW}=1.97 \mathrm{~kg}, \mathrm{p}<0.05\right)$. At weaning, the animals born in rainy season preserve their advantages; they were heavy respectively $+1.2 \mathrm{~kg}$ and $+1.14 \mathrm{~kg}$ than the animals born in $S_{2}$ and $S_{1}$. At 3 months the advantages were from $+1.32 \mathrm{~kg}$ to $+2.10 \mathrm{~kg}$ (table 1). For the Average daily gains, the season also influenced the $\mathrm{ADG}_{03}$ and $\mathrm{ADG}_{09}$. The animals born during $\mathrm{S}_{3}$ were favoured of $+16.2 \mathrm{~g}$ and $+15.1 \mathrm{~g}$ respectively than those born in $S_{2}$ and $S_{1}$. After weaning they kept the respective superiority of $+19.6 \mathrm{~g}$ and $+13.3 \mathrm{~g}$ than those born in $S_{2}$ and $S_{1}$ (Figure 3).

Animals born during the rainy season $\left(\mathrm{S}_{3}\right)$ grow better than those of the other seasons $\left(\mathrm{S}_{1}\right.$ and $\mathrm{S}_{2}$ ), due to the abundance and the availability of food, when pasture resgrowth and became green. However Alexandre et al. (1997) reported the contrary effect due to parasitic stress in the Creole goat in wet environment. After weaning, the weigth decreasing was due to the change in feeding because the animals may emphasize their own aptitudes to be fed. By analogy to bovine species, this situation was observed by Youssao et al. (1997) and Plon (1979) who recommended a complementation for calves after weaning and at the end of the dry season characterized by weak ADG.

The weight decreasing before 8 months corresponds to the beginning of the welding period. The animals born during season $S_{3}$ presented the best ADG between 0-9 month when compared to those of $S_{1}$ and $S_{2}$. This situation is due to the fact that, one month after birth (S1, S2) they return to welding period, crossing the cold period with many stress and mortalities. During the season $S_{1}$, the pregnant goats also crossed the period in which the pasture remains inexistent. The pasture remainder rots to the first rains of April. The goats hardly manage to satisfy their daily needs for maintenance intended for gestation. 


\section{Year of birth}

According to the year of birth, the weakest birth weight was recorded into 2000 . The performances at 3 months were low during 1998; on the other hand the years 1996 and 1998 were favourable for the weight at nine months. The year of birth influenced the weight at one month and the average daily gain from 3 to 9 months $\mathrm{ADG}_{39}(\mathrm{p}<0.005)$. The weakest gain at weaning was recorded in 1997 and the heaviest into 2000 (respectively $47.55 \mathrm{~kg}$ and $61.05 \mathrm{~kg}$ ), with better gain after weaning compared to the other years. The year 1999 presented better gain in nine months.

The performances observed in 1996 and 1998, are explained by the monthly raining average (116.6 mm which gave better pasture) and the external support of the project in terms of zootechnical entrants. The year 2000 was characterized by the declaration of persistent diarrhoea in breeding that explain the weakest weight evolution of the animals. Ba Diao et al. (URL) reported a highly significant effect $(\mathrm{P}<0.001)$ of the year of birth on animals weight from one to three months for Senegal goats. Oumara (1986) showed a significant effect of the year on the weight at 3 month and the average daily gain from 3 to 9 months. In sahelian zone, the annual variations of animal growth are closely related on the climatic conditions and the herbaceous biomass production as previously reported by Boly et al. (2000) in Burkina.

\section{Sexe of kid and type of birth}

The sex influenced the weight at birth $(\mathrm{P}<0.001)$ and the $\mathrm{ADG}_{39}(\mathrm{P}<0.01)$. The males were heavier than the females at birth $(+2.23 \mathrm{~kg}) ;+2.02 \mathrm{~kg}$ at weaning, but at nine months of age the females were favoured of $+1.23 \mathrm{~kg}$, males lose weight at 9 months (Figure 4 ).

The animals born as single weighed respectively $+40 \mathrm{~g}$ and $170 \mathrm{~g}$ heavier than twin and triple. The single and Twin animals show a similar growth until 7 months age. At 8 months of age animals born as single were favoured by $(+30 \mathrm{~g})$ than the twins, and the twins by $+1555 \mathrm{~g}$ than triple. At birth the males were heavier than the females. Those of the simple and triple parturition weighed $300 \mathrm{~g}$ heavier than the females. From 2 to 3 months, the triplet females were $+700 \mathrm{~g}$ heavier than the males. But their growth stopped in 3 months $(8 \mathrm{~kg})$ (Figures 5a-5b-5c). At 8 months of age the males became heaviest $(+4400 \mathrm{~g})$.

The advantage of males over females, have been earlier reported by Robinet (1967), Oumara (1986), Marichatou et al. (2002) in Maradi goats and Alexandre et al. (1997) in the Creole goats. The birth weight of the Maradi goat $(2.12 \mathrm{~kg})$ is slightly higher than that of Bulassa one $(2.05 \mathrm{~kg})$ and not significantly different to Mubende goat ( $2 \mathrm{~kg}$ for males and $1.7 \mathrm{~kg}$ for female) reported by Francis M. Baguma Mbuza (2004). By comparison with the results of Tamboura and Berté (URL), the Maradi goat is heavier $(+1290 \mathrm{~g})$ in nine months than the Mossi goat.

The ADG from birth to 3 months for the males $(55.39 \mathrm{~g} / \mathrm{day})$ is lower than $63 \mathrm{~g} / \mathrm{day}$ announced by Charray et al. (1980) 55.65g/day for the females (Maradi goat). The values obtained in the present study are lower than the performances of Mossi caprine in traditional breeding (Tamboura et al. (URL). 
Vol. 06, No. 01; 2021

ISSN: $2456-8643$

On the other hand the Maradi goat becomes highly efficient than the latter if we considers the period from birth to $300 \mathrm{j}$ (43.42g/day for the Maradi goat females against $40.1 \mathrm{~g} /$ day for the Mossi females and 45.76g/day for the Maradi goat male against $41.8 \mathrm{~g} / \mathrm{day}$ for the Mossi goat). The average daily gain starts to decrease at 3 months. From 0 to 7 months the males have best performance. That is due to the fact that males were commonly heavier than female, and this difference would be due to the morphological(born heavier) and physiological difference (more competitive than the females when suckling). It is unanimously proven that the pre weaning growth, i.e. from birth to 3 months is closely related to the use of mother milk. From 8 months, the females evolve better than the males. That can be explained by their entry in reproduction, it is thus necessary to consider weight gain due to gestation, which passes unperceptible.

\section{Heritability}

The present study and other results shown that post-weaning growth (after 4months) generally has higher heritability estimates than pre-weaning growth (from birth to 4months). Heritability estimates obtained in this study $(0.15+0.1)$ for birth weight, 0.8 for 7 months age (table 4$)$.

"This would indicate that environmental factors, in relation to additive genetic factors, had more influence on early kid gains than on gains later in the kid's life. This may be attributed to the high maternal influence associated with kid growth performance early in life. High maternal influence has a tendency to increase the component of variance environmental to the lamb thereby lowering heritability estimates (Thrift et al 1973)".

\section{CONCLUSION}

The results obtained in the caprine centre are lower by half than the performances obtained in the general country environment.

The non-genetic factors studied (season of birth, year of birth and sex of the kids, range) have all some variables effects on the weight profit and the growth of the russet-red goat of Maradi. The season of birth was the most significant factor and food constitutes a limiting factor. The animals born in $\mathrm{S} 3$ grow better than those of S1 and S2. It would be preferable to determine S3 as low setting period, but it would be necessary to find adequate food after weaning in order to exteriorize their growth potential and to attenuate by rebound the weight decrease because this period is very critical for animal evolution. The decrease of reproduction and production factors obliges to realize pedigree in order to select animals with high performances, and to avoid consanguinity. The study of the non-genetic factors influencing the weight profit and the growth of the animals is a significant stage within the framework of the genetic improvement of Maradi goat. The effect of these factors will be exploited in the selection program because it is imperative to determine a standard curve of growth corrected for these factors likely to introduce errors. The phenotypic variations and the heritability need data from parents about characters of production. All that requires a perfect and organized management of the breeding system.

The higher heritability estimates for 28 weeks (0.8); 20 and 24 weeks (0.6) live weight and gain in this study indicate that to select kids for their own genetic merit for weights and gains, it 
Vol. 06, No. 01; 2021

ISSN: $2456-8643$

would be best to use body weight at 5, 6 and 7 months of age as the selection criterion rather than Birth and weaning weight as is often practiced.

(Thrift et al 1967; Olson et al 1976; Martin et al 1980) cited by Das and Mesfin Shibe enounced that selection directed towards weights at later ages would maximise response in birth weight and possible increased frequency of dystocia. However, selection for weights at later ages would be expected to lead to increased yearling weights which is desirable for meat animals, but may be associated with increased maintenance costs for breeding animals.

\section{Acknowledgements}

The authors thank Belgian Technical cooperation (BTC) granted this study. Dr Baza Alassane, Dr Armand Gbangboche and Issaka Youssao for their critical discussions. Dr Bickou Issifou, Iliassou Yayé Dan Falké, Chaibou Agada.

\section{REFERENCES}

Aboubacar, D., Pandey, V.S., Gouro, S.A., Verhulst, A., 1998. Effect of urea-treated or untreated straw with cotton seeds on performances of lactating Maradi (red sokoto) goats in Niger. Liv. Prod. Sci., 55, 117-125.

Alexandre, G., Aumont, G., Fleury, J., Coopry, O., Muleceba, P., Nepos, A., 1997. Production semi-intensive au pâturage de caprins à viande en zone tropicale: le cas des cabris créoles sur pangola (Digitaria decumbens) en Guadeloupe. [en ligne]. Adresse URL :

http://www.inra.fr/internet/produits/PA/tropical/alex2/g2a971.htm. Consulté le 5 novembre 2003.

Alexandre, G., Aumont, G., Fleury, J., Mainau, J.D., Kandassamy, T., 1999. Performances zootechniques de la chèvre créole allaitante de Guadeloupe : bilan de 20 ans dans un élevage expérimental de l'INRA. [en ligne]. Adresse URL : http://www.inra.fr/internet/produits/PA/tropical/alex1/g1a971.htm. Consulté le 4 décembre 2003.

Anonyme 1999: Centre caprin de Maradi, rapports annuels d'activité de 1990 à 2004.Maradi, Niger.

Apollinaire, Z.M., 1997. Contribution à l'étude des paramètres non génétiques et génétiques de la production laitière des chèvres en Belgique. Thèse de doctorat. Université de Liège. Faculté de Médecine Vétérinaire: Liège, pp. 201.

Bâ Diao, M., Gueye, A., Seck, M., (sans date). Facteurs de variation de la production laitière des caprins en Milieu peul. [en ligne]. Adresse URL : http://www.fao.org/wairdocs/ilri/x5473b/x5473b21.htm. Consulté le 11 décembre 2003.

Bambelo, A., 1961. La chèvre rousse et ses exploitations au Niger. Thèse de fin d'étude. Ecole nationale vétérinaire de Toulouse. France. Pp. 224. 
Boly, H., Some S.S., Kabie, A., Sawadogo., Leroy., P., 2000. Reproduction et croissance du zebu azawak en zone soudano- sahélienne (station de Loumbila au Burkina Faso). Annale de l'Université de Ouagadou, 8, 85-98.

Charray, Y.C., Haumesser, J., Planchenault, D., 1980. Synthèse des connaissances sur l'élevage des petits ruminants dans les pays tropicaux d'Afrique Centrale et d'Afrique de l'Ouest. pp. 295.

Cissé, M., Fall, Y., Ly, I., (sans date). Performances laitières et état nutritionnel des chèvres du sahel conduites sur parcours naturels : relations avec la croissance des chevreaux. [en Ligne]. Adresse URL:

http://www.fao.org/wairdocs/illi/x5473b/x5473b21.htm. Consulté le 11 décembre 2003.

Corcy, J.C., Germain, H., 1991. La chèvre. Maison Rustique : Paris. France. pp. 253.

Devendra, C., Burns, M., 1970. Goat production in the tropics. C.A.B. international: Wallingford, pp.183.

Doutressoule, G., 1947. L'élevage en AOF. Laroche, Paris, Françe. pp. 298.

Faugère, B., 1986. Suivi de troupeau et contrôle de performances individuelles des petits ruminants en milieu traditionnel africain: aspect méthodologique. Revue d'Elevage de Médecine Vétérinaire des Pays tropicaux ., 39, 29 - 40.

Faye, B., 2001. Le rôle de l'élevage dans la lutte contre la pauvreté. R.E.M.V.T, 54, 231 - 238.

Haenlein, G.F.W., 1987. Dairy goat management. J. Dair. Sci., 61, 1011-1022.

Haumesser, J.B., 1975. Quelques aspects de la reproduction chez la chèvre rousse de Maradi, comparaison avec d'autres races tropicales ou subtropicales. Revue d'Elevage de Médecine Vétérinaire des Pays tropicaux., 28, 225 - 234.

Jenness, R., 1980. Composition and characteristics of goat milk. J. Dair. Sci 63, 1605-1630.

Mahamadou, M., 2003. Croissance des cabris roux sevrés, supplémentés à base de calcaire et de phosphate naturel, poudre d'os, au centre d'Elevage Caprin de Maradi, Niger. Mémoire de fin d'étude. Université du Mali, Katibougou, Mali. pp.43.

Marichatou, H., Mamane, L., Banoin, M., Baril, G., 2002. Performances zootechniques des caprins au Niger. Etudes comparatives de la chèvre rousse de Maradi et de la chèvre à robe noire dans la zone de Maradi. Revue d'Elevage de Médecine Vétérinaire des Pays tropicaux .55, $79-84$.

Naves, M., Menende Bruxadera, A., Alexandre, G., Mandonnet, N., 2001. Études comparatives sur la méthodologie d'estimation des poids à âges types avant sevrage appliqué aux caprins créoles Producteurs de viande. Revue d'Elevage de Médecine Vétérinaire des Pays tropicaux. 54, 81-87. 
Vol. 06, No. 01; 2021

ISSN: $2456-8643$

Oumara, A., 1986. Croissance et viabilité de la chèvre rousse de Maradi au Centre d'élevage Caprin de Maradi thèse Médecine Vétérinaire. Institut de médecine vétérinaire tropicale

D’Anvers : Anvers .

Roy R., Prakash B. and Khan B.U. 1989. Genetic and non-genetic sources of variation for growth in Jamunapari kids. Indian Journal of Animal Sciences 59:874-877.

Singh S.K., Sood S.B. and Khan B.U. 1993. Recent Advances in Goat Production. Proceedings of the V International Conference on Goats, held in New Delhi, India, 2-8 March 1992. International Goat Association, New Delhi, India/International Development Research Centre, Ottawa, Canada/Food and Agriculture Organization of the United Nations, Rome, Italy/IndoSwiss Development and Fodder Production Project, Ajmer, Rajasthan, India. pp. 675-678. 
Table 1: least square means and standard errors for adjusted body weights and average daily gains

\begin{tabular}{|c|c|c|c|c|c|c|c|c|c|c|c|c|c|c|}
\hline & & Factors & & & & & & & & & & & & \\
\hline & & Sexes & & & Saison & Of & birth & & Yeard & of & Birth & & & \\
\hline Body & Number & $\mathrm{M}$ & $F$ & Sig & S1 & S2 & S3 & Sig & 1996 & 1997 & 1998 & 1999 & 2000 & Sig \\
\hline Bw & 228 & $2.23 \pm 0.6^{\mathrm{a}}$ & $2.2 \pm 0.5^{b}$ & $* *$ & $2.1 \pm 0.5^{\mathrm{a}}$ & $1.9 \pm 0.7^{b}$ & $2.2 \pm 0.7 c$ & $* *$ & $2.1 \pm 0.9^{\mathrm{a}}$ & $2.4 \pm 1.9^{b}$ & $2.1 \pm 0.4^{\mathrm{a}}$ & $2.1 \pm 0.7^{\mathrm{a}}$ & $1.8 \pm 1.1^{\mathrm{a}}$ & \\
\hline W1 & 160 & $3.8 \pm 1.2^{b}$ & $3.8 \pm 1.2^{b}$ & & $4 \pm 1.2^{a}$ & $3.5 \pm 1.4^{b}$ & $3.8 \pm 1.4 a b$ & & $4.2 \pm 3.9^{a}$ & $4.2 \pm 1.9^{b}$ & $3.6 \pm 0.7^{b}$ & $3.9 \pm 1.5^{b}$ & $3.1 \pm 2.6^{\mathrm{a}}$ & \\
\hline W2 & 275 & $5.9 \pm 1.4^{b}$ & $5.6 \pm 1.3^{b}$ & & $5.5 \pm 1.3^{a}$ & $5.4 \pm 1.7^{a}$ & $6.2 \pm 1.7 \mathrm{~b}$ & & $6.2 \pm 2.7^{a}$ & $6 \pm 2.1^{a}$ & $5.5 \pm 1.1^{b}$ & $5.5 \pm 1.9^{b}$ & $5.5 \pm 3.4^{b}$ & \\
\hline W3 & 312 & $7.4 \pm 1.5^{b}$ & $7.1 \pm 1.5^{b}$ & & $6.8 \pm 1.5^{a}$ & $6.9 \pm 2^{a}$ & $8 \pm 1.9 \mathrm{~b}$ & & $7.4 \pm 2.4^{a}$ & $7.3 \pm 2.4^{a}$ & $6.9 \pm 1.3^{a}$ & $7.3 \pm 2.2^{a}$ & $7.3 \pm 4.1^{\mathrm{a}}$ & \\
\hline W4 & 300 & $9.1 \pm 1.9^{b}$ & $8.7 \pm 1.9 \mathrm{~b}$ & & $8.7 \pm 1.9^{a}$ & $7.9 \pm 2.5^{b}$ & $10.1 \pm 2.4 c$ & $* *$ & $9.1 \pm 3^{a}$ & $9.2 \pm 3.1^{a}$ & $8.8 \pm 1.7^{b}$ & $8.3 \pm 2.8^{b}$ & $9 \pm 5.1 \mathrm{a}$ & \\
\hline W5 & 284 & $10.7 \pm 2.6^{\mathrm{a}}$ & $10.2 \pm 2.4^{\mathrm{a}}$ & & $10.4 \pm 2.5^{\mathrm{a}}$ & $9.2 \pm 3.4^{b}$ & $11.7 \pm 3.1 \mathrm{c}$ & $* *$ & $10.4 \pm 3.9^{a}$ & $10.8 \pm 4^{a}$ & $10.4 \pm 2.3^{a}$ & $10.1 \pm 3.8^{\mathrm{a}}$ & $10.5 \pm 6.6^{a}$ & \\
\hline W6 & 246 & $12.2 \pm 3.1^{a}$ & $11.2 \pm 2.9^{b}$ & $* *$ & $11.3 \pm 3^{a}$ & $10.5 \pm 4.7^{a}$ & $13.3 \pm 3.7 b$ & & $11.8 \pm 4.3 a$ & $11.9 \pm 4.6^{a}$ & $11.7 \pm 2.8^{a}$ & $11.3 \pm 4.9^{a}$ & $12 \pm 7.8^{a}$ & \\
\hline W7 & 224 & $12.8 \pm .8^{a}$ & $12 \pm 3.4^{a}$ & & $11.7 \pm 3.7^{a}$ & $11.1 \pm 4.8^{a}$ & $14.4 \pm 4.5 b$ & & $13.2 \pm 2.2^{a}$ & $12.8 \pm 3.4^{a}$ & $11.9 \pm 3.2^{\mathrm{ab}}$ & $12.3 \pm 3.4^{a}$ & $11.8 \pm 4.8^{\mathrm{ab}}$ & \\
\hline W8 & 173 & $13.4 \pm 5.1^{a}$ & $12.8 \pm 4.2^{a}$ & & $11.9 \pm 4.6^{a}$ & $12.3 \pm 6.1^{a}$ & $15.2 \pm 5.4 b$ & & $14.7 \pm 0.6^{a}$ & $13.2 \pm 0.7^{a}$ & $13.1 \pm 0.3^{\mathrm{ab}}$ & $12.9 \pm 0.8^{a}$ & $11.7 \pm 1.2^{\mathrm{ab}}$ & \\
\hline W9 & 103 & $12.4 \pm 8.3^{a}$ & $13.7 \pm 5.6^{b}$ & $* *$ & $12.8 \pm 6.3^{\mathrm{ab}}$ & $12.1 \pm 9.1^{a}$ & $14 \pm 8.3 b$ & & $15.1 \pm 0.7^{a}$ & $12.7 \pm 1.7^{a}$ & $14.1 \pm 0.4^{a}$ & $11.7 \pm 1.1^{b}$ & $11.5 \pm 1.9^{b}$ & $* * *$ \\
\hline \multirow{2}{*}{$\begin{array}{l}\text { Average } \\
\text { daily } \\
\text { gain (g) } \\
\text { ADG03 }\end{array}$} & & & & & & & & & & & & & & \\
\hline & 223 & $55.3 \pm 2.7^{a}$ & $55.6 \pm 2.4^{\mathrm{a}}$ & & $49.7 \pm 2.5^{a}$ & $50.8 \pm 3.2^{\mathrm{a}}$ & $65.9 \pm 3.2 b$ & $* *$ & $60.1 \pm 4.2^{\mathrm{a}}$ & $47.5 \pm 8.1^{a}$ & $54.6 \pm 1.7^{\mathrm{a}}$ & $54.1 \pm 3.2^{\mathrm{a}}$ & $61 \pm 4.9^{a}$ & \\
\hline ADG39 & 48 & $27.5 \pm 4.3^{a}$ & $37.1 \pm 2.7^{b}$ & $* *$ & $32.1 \pm 3.4^{a}$ & $33.9 \pm 4.3^{a}$ & $30.8 \pm 3.8 a$ & & $41.7 \pm 3.4^{a}$ & $31.6 \pm 5.2^{b}$ & $35.9 \pm 2.1^{b}$ & $16.9 \pm 6.1^{c}$ & $35.5 \pm 1^{b}$ & \\
\hline ADG09 & 34 & $45.7 \pm 0.5^{\mathrm{a}}$ & $43.4 \pm 0.4^{a}$ & $* *$ & $40.5 \pm 0.4^{a}$ & $39.3 \pm 0.5^{a}$ & $53.9 \pm 0.5 b$ & $* *$ & $51.6 \pm 0.4^{a}$ & $35.9 \pm 1.3^{b}$ & $46.1 \pm 0.2^{b}$ & $54.8 \pm 1.3^{a}$ & $34.4 \pm 0.7^{b}$ & \\
\hline
\end{tabular}

$\mathrm{BW}=$ weigth at birth, $\mathrm{W}(\mathrm{i})=$ weight at age (i) (I expressed in month); ADG03 = average daily gain from birth to 3 months; ADG39 = average daily gain from 3 to 9 months, ADG09 = average daily gain from birth to 9 months, $S 1=$ from november to february; $S 2=$ from march to june; $S 3=$ from july to October; $M=$ male,

$\mathrm{F}=$ female; Least square means \pm standard errors within a column not followed by the same letter differ $(\mathrm{p}<0.05)$; NS non significant $(\mathrm{p}>0.05), * *$ significant $(\mathrm{p}<0.01)$ 
Table 2: Least square means (Lsm) and standard errors (S.e.) of live bodyweight of Maradi goats born as single, twin and triple, - within a column not followed by the same letter differ $(p<0.05)$; NS non significant $(p>0.05)$,

\begin{tabular}{|cccc|}
\hline & \multicolumn{3}{c|}{ Litter type } \\
Body weight $(\mathrm{kg})$ & Single & Twin & Triple \\
& Lsm \pm S.e. & Lsm \pm S.e. & Lsm \pm S.e. \\
BW & $2.1 \pm 0.03^{\mathrm{a}}$ & $2.08 \pm 0.03^{\mathrm{a}}$ & $1.9 \pm 0.1^{\mathrm{b}}$ \\
W1 & $3.7 \pm 0.04$ & $3.8 \pm 0.05$ & $3.5 \pm 0.1$ \\
W2 & $5.6 \pm 0.09^{\mathrm{a}}$ & $5.6 \pm 0.1^{\mathrm{a}}$ & $5.4 \pm 0.3^{\mathrm{b}}$ \\
W3 & $7.2 \pm 0.1$ & $7.05 \pm 0.1$ & $6.4 \pm 0.4$ \\
W4 & $8.9 \pm 0.1$ & $8.8 \pm 0.1$ & $7.6 \pm 0.5$ \\
W5 & $10.6 \pm 0.1^{\mathrm{a}}$ & $10.3 \pm 0.2^{\mathrm{b}}$ & $9.3 \pm 0.6^{\mathrm{c}}$ \\
W6 & $11.7 \pm 0.2^{\mathrm{a}}$ & $11.5 \pm 0.2^{\mathrm{a}}$ & $10.09 \pm 0.6^{\mathrm{b}}$ \\
W7 & $12.5 \pm 0.2^{\mathrm{a}}$ & $12.5 \pm 0.2^{\mathrm{a}}$ & $10.1 \pm 0.7^{\mathrm{b}}$ \\
W8 & $13.9 \pm 0.2^{\mathrm{a}}$ & $13.6 \pm 0.2^{\mathrm{a}}$ & $12.1 \pm 0.6^{\mathrm{b}}$ \\
W9 & $14.6 \pm 0.1^{\mathrm{a}}$ & $14.8 \pm 0.1^{\mathrm{a}}$ & $13.9 \pm 0.5^{\mathrm{b}}$ \\
\hline
\end{tabular}

Table 3: Comparison of Maradi red goat weight with other goat growth performances

\begin{tabular}{|c|c|c|c|c|c|c|c|c|c|c|c|}
\hline & \multicolumn{7}{|c|}{ Weight } & \multirow{2}{*}{$\begin{array}{l}\text { GMQ } \\
\text { GMQ }_{03}\end{array}$} & \multirow[b]{2}{*}{$\mathrm{GMQ}_{39}$} & \multirow[b]{2}{*}{$\mathrm{GMQ}_{09}$} & \multirow[t]{2}{*}{ Source } \\
\hline & BW & W1 & W2 & W3 & W4 & W5 & W6 & & & & \\
\hline $\begin{array}{l}\text { Maradi } \\
\text { red goat }\end{array}$ & $2.1 \pm 0.4$ & $3.7 \pm 0.8$ & $\begin{array}{l}5.6 \pm 1 . \\
4\end{array}$ & $\begin{array}{l}7.1 \pm \\
1.7\end{array}$ & $8.8 \pm 2.2$ & $\begin{array}{l}10.4 \pm 2 . \\
7\end{array}$ & $\begin{array}{l}11.6 \pm 3 . \\
1\end{array}$ & $50.1 \pm 2$ & $35.1 \pm 1.5$ & $43.7 \pm 1.1$ & This study \\
\hline $\begin{array}{l}\text { Caprins } \\
\text { arabes }\end{array}$ & $\begin{array}{l}3.6 \pm 0.3 \\
\text { (8jours) }\end{array}$ & & & & $11.3 \pm 0.7$ & & & 74.15 & 30.2 & & $\begin{array}{l}\text { R.Dumas } \\
\text { Rév.Elev.M } \\
\text { ed.vét.pays } \\
\text { trop.1980, } \\
33(2)\end{array}$ \\
\hline $\begin{array}{l}\text { Small } \\
\text { East } \\
\text { African } \\
\text { goat }\end{array}$ & $2.06 \pm 04$ & & $\begin{array}{l}8.3 \pm 1 . \\
5\end{array}$ & & & $\begin{array}{l}19.7 \pm 2 . \\
5\end{array}$ & $\begin{array}{l}21.8 \pm 2 . \\
8\end{array}$ & $84 \pm 18$ & $54 \pm 10$ & & $\begin{array}{l}\text { HSK.Nsubu } \\
\text { ga, small } \\
\text { ruminant ; } \\
\text { oat and } \\
\text { sheep in } \\
\text { Uganda } \\
\text { (1996) }\end{array}$ \\
\hline $\begin{array}{l}\text { Tanzanie } \\
\text { hybride } \\
\text { goat }\end{array}$ & $\begin{array}{l}2.4 \pm 0.0 \\
2\end{array}$ & & & & $\begin{array}{l}17.14 \pm 0 . \\
1\end{array}$ & $\begin{array}{l}12.4 \pm 0 . \\
6\end{array}$ & & 80.01 & 592 & $41.1 \pm 1$ & $\begin{array}{l}\text { Parameter } \\
\text { genetique } \\
\text { de la } \\
\text { chevre } \\
\text { hybryde de } \\
\text { Tanzanie }\end{array}$ \\
\hline $\begin{array}{l}\text { Caprin en } \\
\text { milieu } \\
\text { peul }\end{array}$ & $\begin{array}{l}2.2 \pm 0.6 \\
\text { (male) }\end{array}$ & $4.6 \pm 1$. & & $\begin{array}{l}8.7 \pm \\
2\end{array}$ & & & $13.2 \pm 3$ & $66.7 \pm 26$ & $50.6 \pm 25$ & $36.7 \pm 11$ & $\begin{array}{l}\text { Ba,Diao.an } \\
\text { d al }\end{array}$ \\
\hline $\begin{array}{l}\text { Creole } \\
\text { goat }\end{array}$ & 1.84 & & & 8.2 & & & & 83 & & & $\begin{array}{l}\text { Devendre, } \\
\text {., Marca } \\
\text { Burns, } \\
1997\end{array}$ \\
\hline
\end{tabular}


Table 4: Heritability estimates on growth traits of Maradi russet goat and comparison with blended goat kids in Malya, Dairi goat and Jamunapari kids.

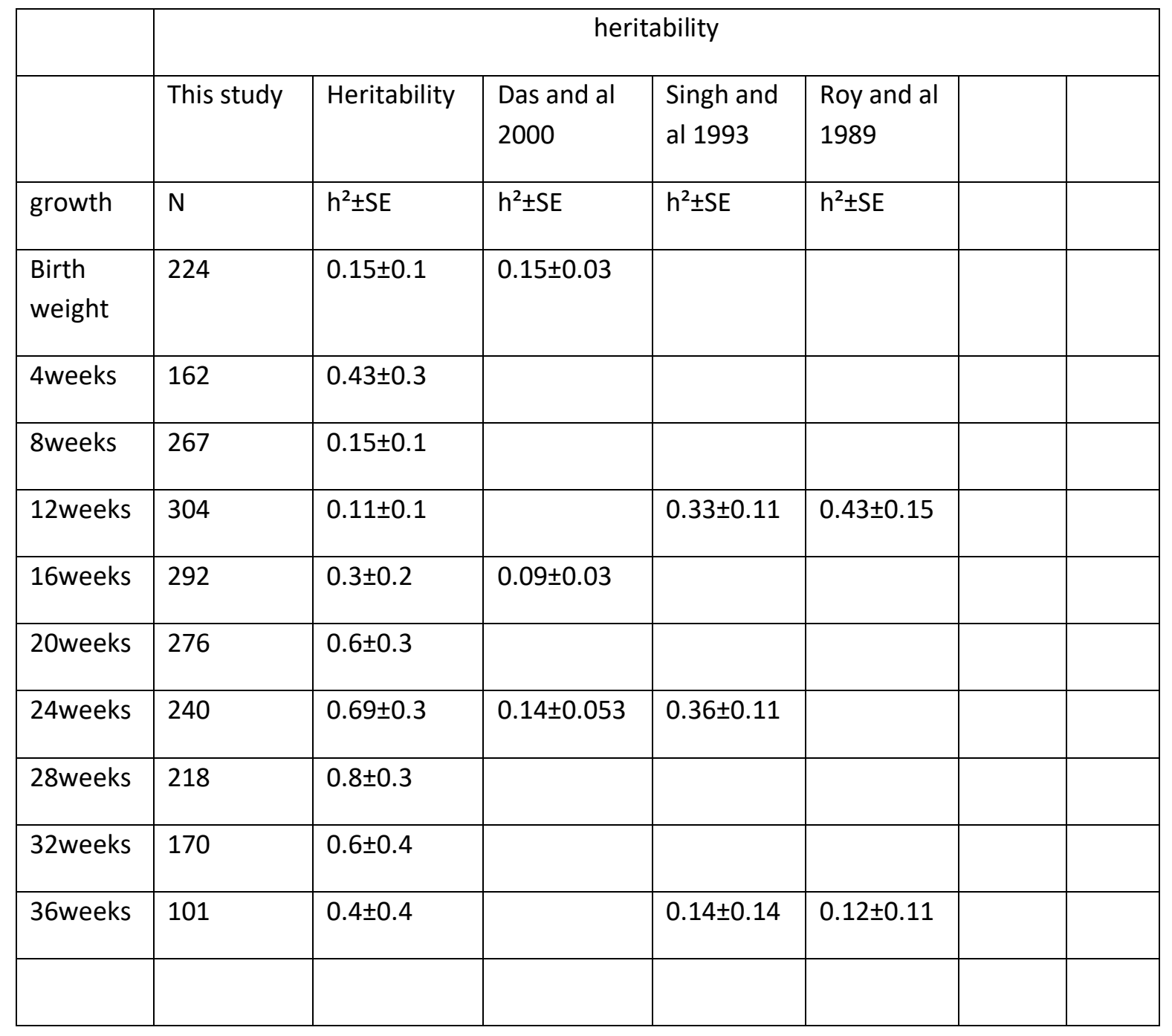

$\mathrm{BW}=$ weight at birth, $\mathrm{W}$ (i) = weight at age (i) (I expressed in month); ADG03 = average daily gain from birth to 3 months; ADG39= average daily gain from 3 to 9 months

\section{FIGURES}

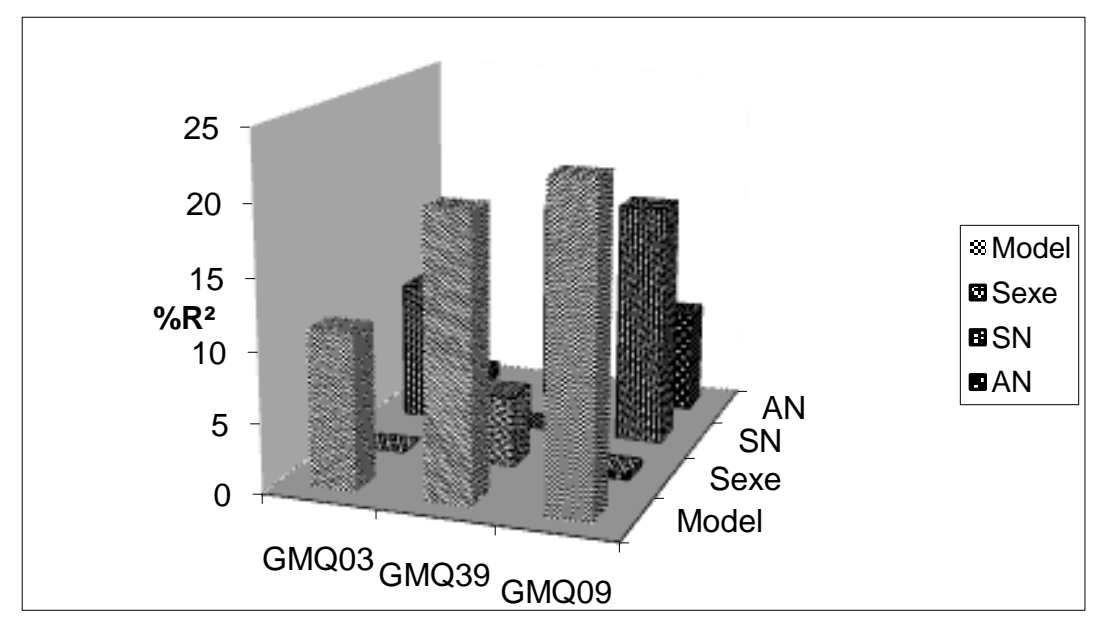

( $\mathrm{SN}=$ season of birth and $\mathrm{AN}=$ year of birth).

Figure 1: $\mathrm{R}^{2}(\%)$ variation explained by the model and non-genetic factors:

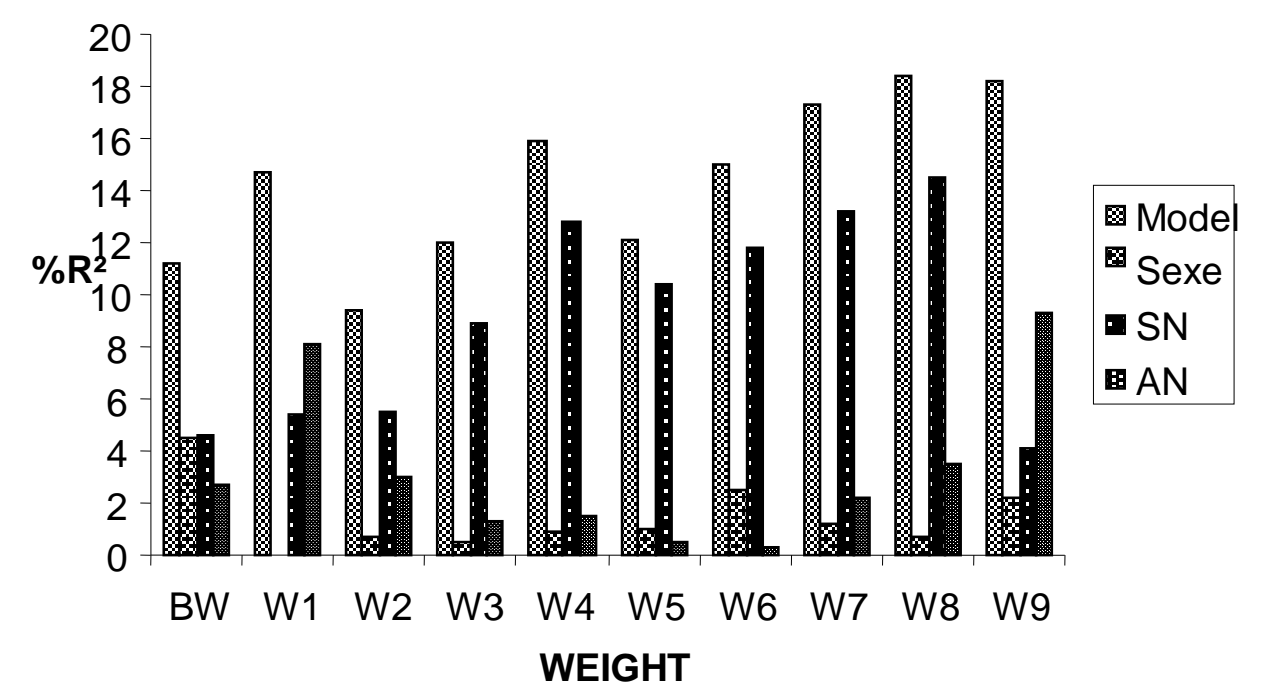

Figure 2: variation of the fixed factors explained by the model 


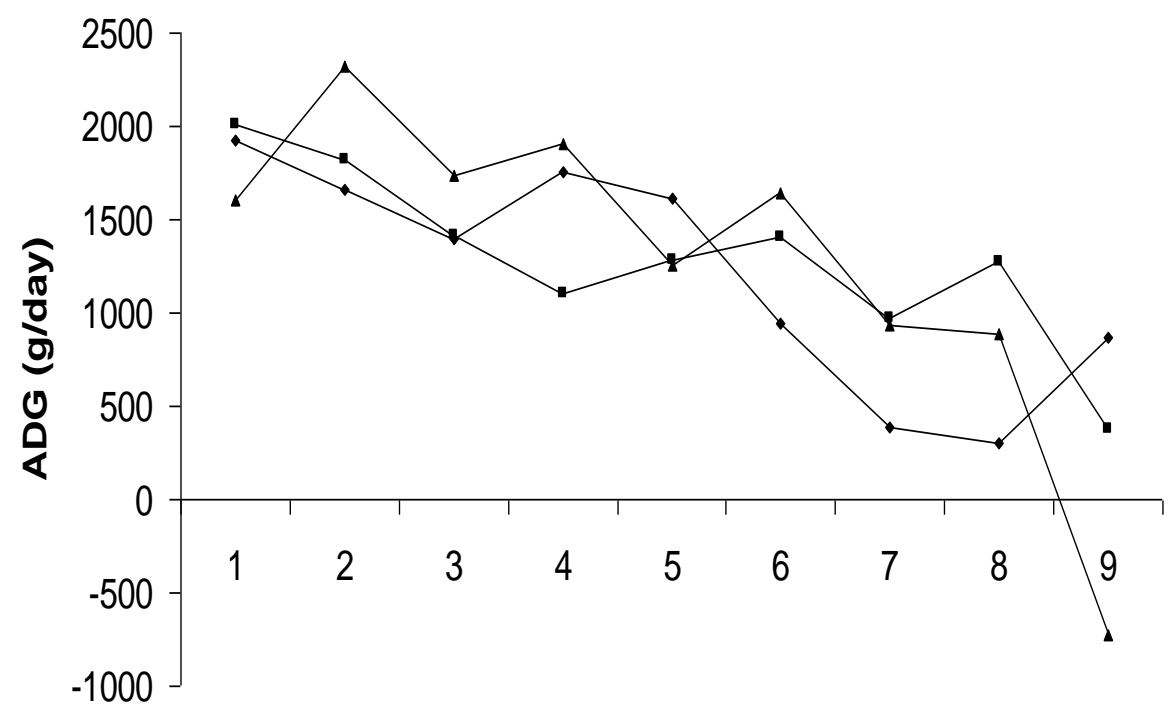

Age (month)

$\rightarrow-S 1 \rightarrow-S 2+S 3$

S1= November to February; S2= March to June; S3= July to October $(\mathrm{SN}=$ season of birth and $\mathrm{AN}=$ year of birth; Bw = weight at birth, W(i)= weight at age (i), i per month

Figure 3: Influence of birth season on the average daily gain from 1 to 9 months.

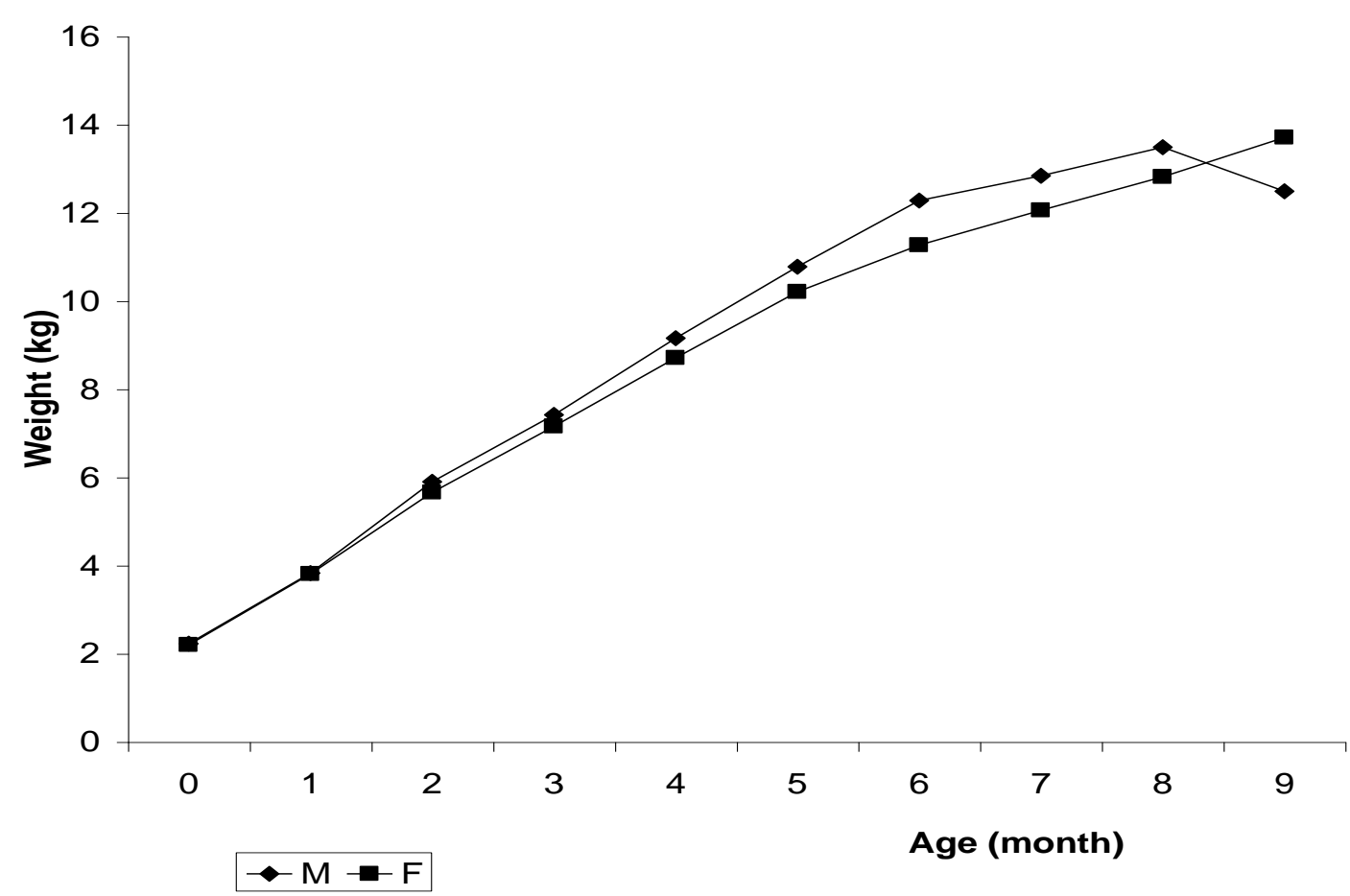

$\mathrm{M}=$ male $; \mathrm{F}=$ female

Figure 4: Weight evolution of Maradi goat according to the sexes

A. Simple

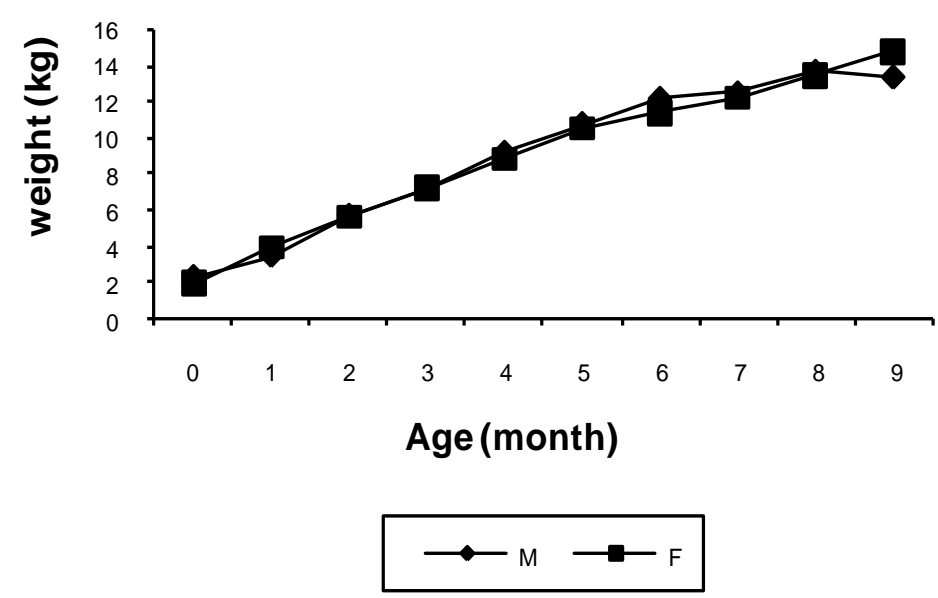


B. Double

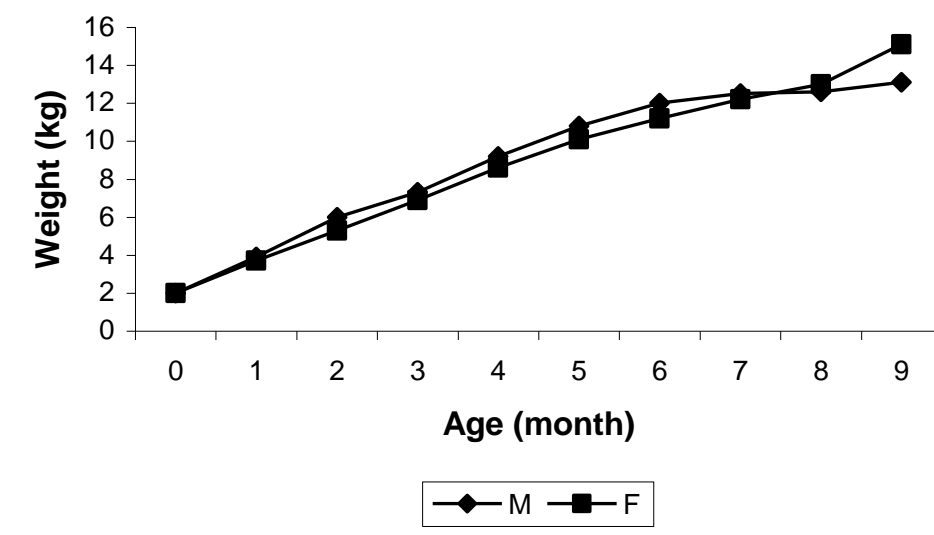

C. Triple

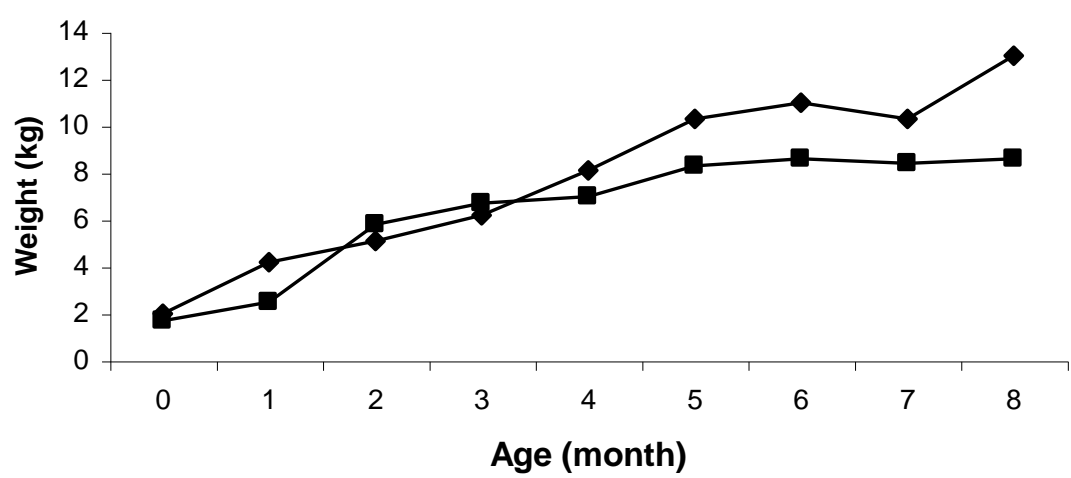

Figure 5: Influence of the sex and the type of birth on weight evolution 